\title{
Komentarze
}

\section{Żydzi i zagłada w polskich kulturach pamięci: między antagonizmem $i$ agonem}

Sławomir Kapralski

TEKSTY DRUGIE 2016, NR 6, S. 346-357

DOI: $10.18318 /$ td.2016.6.20

nspiracją dla tych rozważań była ponowna lektura wywiadów zebranych na początku lat 90. w ramach projektu „Pamięć kultury żydowskiej wśród mieszkańców Podkarpacia", kierowanego przez profesorów Jonathana Webbera (wówczas z Oxfordu) i Andrzeja Palucha (Instytut Socjologii UJ). W czasie trwania projektu, który - wbrew nazwie - objął swoim zasięgiem cały teren dawnej polskiej Galicji, przeprowadzono kilkaset pogłębionych wywiadów z ludźmi, którzy w momencie wybuchu II wojny światowej byli już na tyle dorośli, by mieć własne wspomnienia o swoich żydowskich sąsiadach. Po ponad dwudziestu latach niektórzy uczestnicy tamtych badań postanowili powrócić do zebranego wówczas materiału i włączyć jego analizę do nowego projektu badawczego „Strategie pamiętania o kulturze żydowskiej w Galicji".

Powrót do materiału zebranego w zupełnie innym czasie stanowi fascynujące doświadczenie, pouczające o tym, jak bardzo interpretacja zależy od kontekstu, w jakim się dokonuje: zarówno gdy mówimy o interpretacji materiału dostarczonego nam przez badanych, jak
Tekst powstał w ramach grantu NCN OPUS 4 DEC-2012/07/B/HS3/03464 "Strategie pamiętania o kulturze żydowskiej w Galicji". Został napisany w trakcie pobytu w Swedish Collegium for Advanced Study w Uppsali, możliwemu dzięki EURIAS Fellowship Programme i Marie-Sklodowska-Curie Actions COFUND Programme-FP7.

Sławomir Kapralski

- socjolog, dr hab., prof. Uniwersytetu Pedagogicznego w Krakowie i Senior EURIAS Fellow w Swedish Collegium for Advanced Study w Uppsali. Wykładowca Center for Social Studies przy IFIS PAN w Warszawie. Absolwent Uniwersytetu Jagiellońskiego, gdzie rozpoczął pracę naukowo-dydaktyczną, następnie przez wiele lat związany z Central European University w Pradze, Warszawie i Budapeszcie. 
i o interpretacjach, których dokonywali badani, by udzielić nam odpowiedzi na nasze pytania.

W czasie przeprowadzania wywiadów towarzyszyło nam dość naiwne przeświadczenie, że ludzie, z którymi rozmawiamy, przekazują nam po prostu to, co zdołali zapamiętać i czego w przeszłości dowiedzieli się o Żydach. Mieliśmy zatem tendencję do ujmowania ich komunikatów jako przejawów pamięci rozumianej jako mnéme, a więc przekazywania w czasie odciśniętych we wspomnieniu doświadczeń przeszłych wydarzeń. Ujmując rzecz krótko, wydawało nam się, że nasi rozmówcy przekazują nam po prostu zapamiętany przez siebie obraz Żydów i ich zagłady.

Jednakże już 25 lat temu stanęliśmy w obliczu faktu, że wywiady z jednej strony zawierały wątki fantastyczne, mitologiczne niemalże, które nie mogły się odnosić do realnych wydarzeń z przeszłości, z drugiej zaś - nasi rozmówcy nie poruszali rozmaitych tematów, których musieli być świadomi. Takie treści interpretowane są w polskiej literaturze przedmiotu jako rezultat działania specyficznego wzoru kulturowego', jako rezultat wyparcia poczucia winy za krzywdy wyrządzone Żydom i przeniesienia na nich negatywnych aspektów zbiorowej podświadomości nieżydowskich Polaków² lub wreszcie jako przejaw antysemityzmu (w niemal wszystkich podejściach).

Perspektywy te doprowadziły do znakomitych rezultatów badawczych, niemniej jednak mają też swoje wady. Odniesienie do ramy kulturowej może prowadzić do apodyktycznej wizji niezmiennej pamięci, zdeterminowanej przez kulturowy wzór myślenia danej społeczności, odizolowany od innych, homogeniczny i statyczny oraz powiązany z równie statycznie postrzeganą, raz na zawsze daną tożsamością. Odniesienie do traumy i mechanizmów jej wypierania bywa w badaniach nad pamięcią krytykowane jako nieadekwatne w analizie mechanizmów społecznych, które charakteryzują zbiorowości, nieokreślone i oparte na niedających się sprawdzić założeniach, a także posługujące się pasywną koncepcją człowieka, zdeterminowanego przez siły, których działania nie jest świadomy.

Jeśli zaś chodzi o wyjaśnienia w kategoriach antysemityzmu, to są one często obciążone błędami logicznymi (regressus ad infinitum, błędne koło), a także milcząco zakładają procedurę esencjalizacji tych, którym się antysemityzm przypisuje. Warto na marginesie zauważyć tu pewną asymetrię: esencjalizowanie kategorii społecznych jest wprawdzie powszechnie krytykowane,

1 A. Cała WizerunekŻyda w polskiej kulturze ludowej, Wydawnictwa UW, Warszawa 1992.

2 J. Tokarska-Bakir Rzeczy mgliste. Eseje istudia, Pogranicze, Sejny 2004. 
jednakże z reguły tylko wtedy, gdy dotyczy „dobrych” (np. mniejszości). Natomiast esencjalizowanie „złych” (np. większości) nie spotyka się już z tak zmasowaną krytyką.

Nie negując istnienia i znaczenia antysemityzmu, skłonny byłbym traktować go nie jako ukształtowaną dyspozycję, trwale charakteryzującą pewne grupy (choć i takie istnieją), lecz - idąc za Wolfgangiem Benzem³ - jako kod kulturowy, uaktywniany w określonych okolicznościach i wykorzystywany jako katalizator i wspólny mianownik wielu różnych, często wzajemnie wykluczających się tendencji społecznych i politycznych. W takim ujęciu antysemityzm, zwłaszcza w okresach przemian społecznych o charakterze kryzysu, nabiera szerokiego znaczenia, wykraczając poza wrogość wobec Żydów. Jest on mianowicie jednym z elementów procesu restrukturalizacji „świata życia” jednostek i grup w celu uporządkowania go i nadania mu na nowo znaczenia.

Doszukiwanie się czynników warunkujących pamięć poza teraźniejszością, w traumatyzujących wydarzeniach z przeszłości lub w pozahistorycznych wzorach kulturowych, może prowadzić do niedoceniania roli teraźniejszych kontekstów sytuacyjnych, w których wytwarza się pamięć społeczna. Jak to ujął Jonathan Friedman: „przeszłość jest zawsze praktykowana w teraźniejszości, nie dlatego, że się narzuca ludziom teraźniejszym, lecz dlatego, że kształtują ją oni praktykując swą tożsamość społeczną. [...] Przeszłość, która oddziałuje na teraźniejszość jest przeszłością wytwarzaną i/lub reprodukowaną w teraźniejszości"“.

Nie jest to myśl nowa: przyświecała już w latach 20. ubiegłego wieku pionierowi socjologicznych studiów nad pamięcią, Maurice'owi Halbwachsowi, który twierdził, że kiedy mówimy o pamięci, to mamy na myśli nie tyle to, co ludzie naprawdę pamiętają, ile raczej to, co mówią oni o przeszłości (lub mogliby powiedzieć) w określonych (teraźniejszych) okolicznościach społecznych ${ }^{5}$. Jednakże ciągle jeszcze rzadko stosuje się ją w konkretnych badaniach, które najczęściej wpisują się w bardziej zdroworozsądkowe pojmowanie pamięci jako „odcisku” przeszłości. Jest to poniekąd spowodowane naiwnością badaczy, którzy nie zawsze biorą sobie do serca twierdzenie Alfreda Schütza, że problemy naukowe różnią się od problemów życiowych badanych.

3 W. Benz Anti-Semitism in Europe. Traditions, Structures, Manifestations, Uppsala University, Uppsala 2004.

4 J. Friedman Cultural Identity and Global Process, Sage, London 1994, s. 141.

5 M. Bloch Anthropology and the Cognitive Challenge, Cambridge University Press, Cambridge 2012, s. 8 . 
Ci ostatni nie ułatwiają nam zadania, gdyż po trosze z uprzejmości, a po trosze z konieczności udzielają nam odpowiedzi na pytania o przeszłe wydarzenia w formie w miarę uporządkowanych sekwencji myślowych, w których to, co przeszłe, determinuje to, co teraźniejsze (Schütz powiedziałby, że posługują się „motywem ponieważ”), natomiast w istocie rzeczy dokonują oni w teraźniejszej sytuacji wywiadu kreatywnych zabiegów na materii swoich wspomnień, aby coś osiągnąć (a więc w terminologii Schütza - posługują się, choć najczęściej nie są tego świadomi, „motywem ażeby”)

Czym było to „coś”, co chcieli osiągnąć nasi rozmówcy, gdy opowiadali nam o Żydach 25 lat temu? Z perspektywy czasu odnoszę wrażenie, że za pomocą narracji przeszłych wydarzeń starali się uczynić lęk egzystencjalny, związany z radykalną transformacją ich świata, która dokonywała się na początku lat 90., czymś, co da się przecierpiećn. Trzeba pamiętać, że nasi rozmówcy byli ludźmi starszymi, na ogół słabo wykształconymi, zamieszkującymi małe miejscowości i wioski południowej Polski. Nie zostali beneficjentami przemian i patrzyli w przyszłość z niepokojem. W rozmowach z nami starali się stworzyć lub odtworzyć układ znaczeń, w ramach którego mogliby inscenizować swoje życie ${ }^{8}$, składający się z „opowieści o sobie samym”, budowanych z kodów kulturowych, tradycji literackich, mitów i legend, które mieszają ze sobą fakty, wspomnienia i wyobrażenia, a więc z tego, co Paul Ricœur określał jako „tożsamość narracyjną”. Za pomocą tych opowieści jednostki i grupy nadają znaczenie swojej przeszłości, teraźniejszości i przyszłości, porządkując zarazem epizody swojej historii. W ten sposób starają się wytworzyć w akcie wspomnienia siebie samych jako zdolnych do kontroli losu i chaosu przez odwołanie się do podobnych sytuacji z przeszłości, przez które przeszły, zachowując integralność (lub tak przynajmniej im się wydawało). Jest to przykład wysiłku na rzecz kontrolowania przygodności, który umożliwia nam znalezienie lub nadanie sensu otaczającej nas rzeczywistości i naszego w niej miejsca ${ }^{10}$.

6 A. Schütz O wielości światów. Szkice z socjologii fenomenologicznej, przeł. B. Jabłońska, wyd. 2 poprawione, Nomos, Kraków 2012, s. 133-135.

7 C. Geertz The Interpretation of Culture, Basic Books, New York 1973, s. 104.

8 C. Geertz Zastane światło. Antropologiczne refleksje na tematy filozoficzne, przeł. Z. Pucek, Universitas, Kraków 2003, s. 27.

P. Ricœur O sobie samym jako innym, przeł. B. Chełstowski, PWN, Warszawa 2003.

10 H.C. White Tożsamość i kontrola, przeł. A. Hałas, Nomos, Kraków 2011, s. 11. 
Tym samym, w dzisiejszym odczytaniu zebranych 25 lat temu wywiadów skłonny byłbym posłużyć się wizją pamięci jako anamnesis, w znaczeniu, jakie nadaje temu terminowi Yosef Yerushalmi ${ }^{11}$, a więc jako kontekstowo uwarunkowanego odtworzenia przeszłości, które pełni określone funkcje $\mathrm{w}$ tworzeniu lub podtrzymywaniu tożsamości zbiorowych ${ }^{12}$. W procesie takiego odtwarzania przeszłości wytwarzamy jej wyobrażenia, w których ślady minionego czasu są przefiltrowane i przekształcone przez teraźniejszą przestrzeń znaczeń i interesów, w której istniejemy, i sieci komunikacyjne, w których uczestniczymy ${ }^{13}$.

Powroty do przeszłości dokonywane w celu wzmocnienia teraźniejszych tożsamości często prowadzą do nostalgicznego obrazu „dawnych, dobrych czasów", pocieszającego w okresie kryzysu ${ }^{14}$. W ramach takich wspomnień Żydzi byli często przedstawiani z sympatią, jako część nostalgicznego krajobrazu młodości, w którym dominowało przyjazne współżycie obu grup, a przypadki konfliktów i uprzedzeń wobec Żydów były z takich wspomnień usuwane.

Innym mechanizmem pamięci jako anamnesis jest opisana przez Dominicka LaCaprę ${ }^{15}$ relacja między strukturalną traumą teraźniejszej transformacji i historycznymi traumami doświadczanymi w przeszłości. Lęki związane z tą pierwszą często są reprezentowane we wspomnieniach tych drugich. Nasi rozmówcy, którzy boleśnie doświadczyli transformacji ustrojowej, tracąc w niej swój świat, w którym czuli się zadomowieni, porównywali tę sytuację do podobnych doświadczeń historycznych, z konieczności koncentrując się na okresie II wojny światowej i powojennej transformacji komunistycznej. Wspomnienie wojny oznaczało zaś nieuchronnie spotkanie z losem żydowskim. Ci, którzy przeżyli, natrafiali we wspomnieniach na tych, którzy w większości nie przeżyli.

Takie spotkanie oznaczało podważenie zasadności jednego z najważniejszych polskich dyskursów historycznych - dyskursu „martyrologicznego",

11 Y.H. Yerushalmi Zakhor: Jewish History and Jewish Memory, University of Washington Press, Seattle 1996, s. 107.

12 Jest to więc rozumienie bliższe arystotelesowskiej niż platońskiej koncepcji anamnesis. Por. P. Ricœur Pamięć, historia, zapomnienie, przeł. J. Margański, Universitas, Kraków 2007, s. 27-34.

13 G. Delanty Social Theory in a Changing World. Conceptions of Modernity, Polity Press, Cambridge 1999, s. 71.

14 P. Sztompka Cultural Trauma. The Other Face of Social Change, "European Journal of Social Theory" 2000 Vol. 3, No. 4, s. 284. 
w którym naród polski jest przedstawiany jako największa ofiara procesów historycznych, jako ofiara par excellence ${ }^{16}$, mająca znaczenie eschatologiczne, niedoceniane jednak przez świat, a jednocześnie demonstruje zdolność przetrwania w najtrudniejszych nawet okolicznościach.

Pamięć o Żydach i ich zagładzie była więc dla naszych rozmówców uwikłana w procesy budowania „bezpieczeństwa mnemonicznego" ${ }^{17}$, w trakcie których usuwane są wspomnienia mogące stanowić zagrożenie dla tożsamości i integralności danej grupy oraz wizji świata posiadanej przez jej członków. Innymi słowy, bezpieczeństwo mnemoniczne jest narzędziem zbiorowej walki grupy o zaistnienie wyobrażonej przez nią przyszłości, nadającej poczucie ciągłości historii i zwiększającej zdolność przetrwania, która toczona jest na terytorium równie wyobrażonej przeszłości, przy założeniu, że "gęsta” przeszłość, dająca powody do dumy, jest gwarancją pomyślnej przyszłości, wręcz nieśmiertelności zbiorowej ${ }^{\mathbf{1 8}}$. Nieśmiertelność jest jednak relacją społeczną: jedne grupy osiąają ją kosztem innych, których historie zostają wymazane z pamięci. Procesy takiego „różnicującego pozbawiania historii” ${ }^{19}$ aktywują się szczególnie w okresach kryzysów zagrażających poczuciu ciągłości historycznej i prowadzą do antagonizmu pamięci grupowych.

W rezultacie takich procesów nieżydowscy Polacy, z którymi rozmawialiśmy w latach 90., koncentrowali się na własnych cierpieniach związanych z czasem wojny i postrzegali nieporównanie większe cierpienia Żydów jako antagonistyczną konkurencję. Wyrażało się to m.in. w nieumiejętności ogólnego określenia tego, co stało się z Żydami: nasi rozmówcy często potrafili przekazać nam mnóstwo szczegółów dotyczących zagłady Żydów w ich wsiach i miasteczkach, czasami robiąc to z empatią, czasem z obojętnością, ogólnie jednak tragiczny los Żydów był przez nich postrzegany jako jeden z wielu epizodów „okupacji”, z ich punktu widzenia - nie najważniejszy. Można więc zgodzić się z Michaelem Steinlaufem ${ }^{20}$, gdy pisze, że nieżydowscy Polacy, będący świadkami Holokaustu, widzieli, co się działo, lecz nie wiedzieli,

S. Krajewski Poland and the Jews. Reflection of a Polish Polish Jew, Austeria, Kraków 2005, s. 212.

M. Mälksoo „Memory Must Be Defended”: Beyond the Politics of Mnemonical Security, "Security Dialogue" 2015 Vol. 46, No 3, s. 221.

\footnotetext{
Z. Bauman Mortality, Immortality and Other Life Strategies, Polity Press, Cambridge 1992, s. 55.

Tamże.

M.C. Steinlauf Bondage to the Dead. Poland and the Memory of the Holocaust, Syracuse University Press, Syracuse 1997.
} 
co się stało: nie mieli świadomości bycia świadkami wydarzenia przekształcającego historię.

Jednakże właśnie w tym momencie, gdy nasze rozmowy kierowały się w stronę zagłady Żydów, wielu naszych rozmówców zaczynało odwoływać się do wątków antysemickich, które nie występowały w ich wcześniejszych wypowiedziach. Wyglądało to tak, jakby kod antysemicki (czy to w wersji tradycyjnego antyjudaizmu, czy też nowoczesnego antysemityzmu politycznego) uaktywniał się właśnie wtedy, gdy raz jeszcze zostawali zmuszeni do konfrontacji z wydarzeniem, którego sobie poznawczo nie przyswoili. W ten sposób byli w stanie potraktować Holokaust jako coś mieszczącego się w logice historii i w pewnym sensie uzasadnionego - miała to być kara, jaka spadła na tych, którzy odrzucili prawdziwą wiarę i zabili Boga (tradycyjny antyjudaizm) lub którzy spiskują przeciwko całemu światu (a zwłaszcza przeciwko Polsce - Chrystusowi narodów), aby go opanować.

Tak więc usytuowanie wspomnień o Żydach w polu walki o „bezpieczeństwo mnemoniczne" $\mathrm{i}$,zbiorową nieśmiertelność" prowadzi do antagonistycznej percepcji, uniemożliwiającej empatyczną identyfikację z ofiarami Holokaustu (z wyjątkiem indywidualnych Żydów, dobrze znanych rozmówcom).

Antagonizm pamięci jest tu rozumiany zgodnie z dokonanym przez Chantal Mouffe rozróżnieniem antagonizmu i agonizmu: ten pierwszy jest walką między wrogami, którzy dążą do wzajemnej eliminacji, ten drugi - między adwersarzami, którzy wprawdzie się ze sobą nie zgadzają, niemniej jednak są częściowo otwarci na poglądy drugiej strony i przyznają sobie nawzajem prawo do pozostawania przy swoim zdaniu ${ }^{21}$. Celem demokratycznej polityki jest zdaniem Mouffe przekształcenie antagonizmu w agonizm: stworzenie warunków do ekspresji poglądów i emocji dotyczących spraw, które pozwalają na identyfikację zbiorową, bez równoczesnej konstrukcji Innego jako wroga ${ }^{22}$.

W dziedzinie studiów nad pamięcią koncepcji agonizmu odpowiadają np. idee „mnemonicznego pluralizmu"23, „wielokierunkowości pamięci" ${ }^{24}$

21

Ch. Mouffe Deliberative Democracy or Agonistic Pluralism, Department of Political Science, Institute for Advanced Studies (IHS),Vienna 2000, s. 16.

Tamże.

M. Mälksoo „Memory Must Be Defended"...

M. Rothberg Multidirectional Memory: Remembering the Holocaust in the Age of Decolonization, Stanford University Press, Stanford 2009. Wydanie polskie: M. Rothberg Pamięć wielokierunkowa. Pamiętanie Zagłady w epoce dekolonizacji, przeł. K. Bojarska, Wydawnictwo IBL PAN, Warszawa 2016. 
czy „policentrycznej pamięci społecznej”25. Wszystkie te koncepcje, podobnie jak i opozycja Mouffe, opierają się niestety na oświeceniowej iluzji, że ludzie są zasadniczo racjonalni i mogą się zmienić, jeśli zostaną przekonani. Iluzoryczny charakter takich przekonań ujawnia się szczególnie wyraźnie w czasach kryzysu i zagrożenia. Wydaje się, że bardziej realistyczny obraz funkcjonowania pamięci w czasach transformacji przedstawił Richard Terdiman ${ }^{26}$, według którego jednostki i społeczeństwa w kryzysie zazwyczaj odrzucają wszelkie rewizje pamięci, aby nie osłabiać własnych zasobów symbolicznych. Co więcej, budując wizje przeszłości, posługują się dychotomiami pojęciowymi, które doskonale wpisują się w paradygmat antagonistyczny, z grupą własną przeciwstawioną wrogim i zdradzieckim knowaniom Innych. Wspomnienia tego rodzaju są ekskluzywne: koncentrują się na wyidealizowanej przeszłości danej grupy, do której tylko ona przypisuje sobie prawo. Nawet więc jeśli Michael Rothberg ma rację, że w rzeczywistości żadna grupa nie może sobie rościć praw do wyłącznego posiadania tego, co postrzega jako swoją historię̨ ${ }^{27}$, to jednak jest to dokładnie to, co grupy znajdujące się w sytuacji kryzysowej robią, a wytwarzane przez nie iluzje są realne, ponieważ organizują myślenie i działanie ich członków.

Mimo wszystko jednak pamięć żydowska nie dała się wyeliminować w procesie specyficznej anamnesis czasu transformacji lub zredukować do roli nostalgicznej atrakcji turystycznej. Wręcz przeciwnie: po 1989 roku wykonano ogromną pracę, dzięki której Polska dzisiejsza, w następstwie szeregu wydarzeń, debat, sporów, polemik, publikacji, akcji (i kontrakcji) upamiętniających, jest miejscem, gdzie „pamięta się Żydów” zupełnie inaczej niż na początku lat $90 .{ }^{28}$ Można powiedzieć, że w sferze publicznych, instytucjonalnych działań upamiętniających, choć często o dość elitarnym charakterze, pamięć Żydów i ich zagłady jest obecna (choć nie wiadomo, jak trwale, biorąc pod uwagę odmienne preferencje obecnych elit politycznych w kwestii polityki historycznej).

25 R. Sennett Disturbing Memories, w: P. Fara, K. Patterson (eds.) Memory. Cambridge University Press, Cambridge 1998.

26 R. Terdiman Present Past. Modernity and the Memory Crisis, Cornell University Press, Ithaca 1993, s. 31-38.

M. Rothberg Multidirectional Memory..., s. 5 .

28 P. Forecki Od "Shoah" do "Strachu". Spory o polsko-żydowska przeszłość i pamięć w debatach publicznych, Wydawnictwo Poznańskie, Poznań 2010. 
Jednakże upamiętnienie w płaszczyźnie pamięci kulturowej nie oznacza, że Żydzi i Holokaust stali się integralną częścią pamięci komunikacyjnej w skali masowej ${ }^{29}$. Można powiedzieć, że są oni upamiętniani, ale nie pamiętani. Przyczyn takiego stanu rzeczy jest wiele i zostały one (zwłaszcza te związane z czasem Zagłady, z antysemityzmem czy z problemami polskiej podświadomości zbiorowej) z finezją zbadane w perspektywie kulturowej oraz inspirowanej psychoanalizą. W prezentowanym tu ujęciu pamięci jako anamnesis pytanie o odrzucenie bądź nieprzyswojenie sobie pamięci traktowane jest jako rezultat odrzucenia dyskursu, w którym pamięć ta jest dana, jako nieprzystającego do aktualnych potrzeb grupy dokonującej takiego odrzucenia. Tym samym, zgodnie ze „społeczną teorią traumy” Jeffreya Alexandra ${ }^{30}$ pytanie o to, dlaczego nasi rozmówcy nie zdawali sobie sprawy z tego, czego doświadczyli jako świadkowie Holokaustu, można przekształcić w pytanie, dlaczego odrzucili narrację, która wyposażyłaby ich pamięć w znaczenie i tym samym umożliwiłaby im adekwatne rozpoznanie tego, czego doświadczyli.

Narracja taka pojawiła się w Polsce lat 9o., z jednej strony jako lokalny wysiłek na rzecz odkrywania historii przemilczanej w okresie komunizmu, z drugiej - pod postacią zglobalizowanego dyskursu Holokaustu, który właśnie w tym okresie zaczął funkcjonować jako podstawa reorganizacji aksjologicznego konsensusu w Europie Zachodniej po likwidacji żelaznej kurtyny oraz jako normatywny standard dla dawnych krajów komunistycznych, dążących do włączenia w system europejski ${ }^{31}$.

Jednakże narracja ta, nie tylko w Polsce, ale także w innych krajach Europy Wschodniej, nie znalazła powszechnej akceptacji, lecz stała się raczej kolejnym wymiarem podziałów społecznych ${ }^{32}$. Niewątpliwie jedną z przyczyn

29 Na temat rozróżnienia pamięci kulturowej i komunikacyjnej zob. J. Assmann Pamięć kulturowa. Pismo, zapamiętywanie i polityczna tożsamość w cywilizacjach starożytnych, przeł. A. Kryczyńska-Pham, Wydawnictwa UW, Warszawa 2008, s. 66-71.

J.C. Alexander Trauma. A Social Theory, Polity Press, Cambridge 2012.

D. Levy, N. Sznaider The Holocaust and Memory in the Global Age, Temple University Press, Philadelphia 2006.

32 S.J. Cohen Politics Without a Past. The Absence of History in Postcommunist Nationalism, Duke University Press, Durham 1999; M. Shafir Denying the Holocaust where it Happened. Post-Communist East Central Europe and the Shoah, w: R. Lentin (ed.) Re-presenting the Shoah for the Twenty-First Century, Berghahn Books, New York-Oxford 2004i J.-P. Himka Obstacles to the Integration of the Holocaust into Post-Communist East European Historical Narratives, "Canadian Slavonic Papers/Revue canadienne des slavistes" 2008 Vol. L, Nos. 3-4. 
takiego stanu rzeczy była reakcja obronna na związane z nią otwarcie dyskusji o współudziale nieżydowskich Polaków w Holokauście oraz o konsekwencjach zagłady Żydów dla struktury społecznej, w wyniku których wielu Polaków po wojnie stało się tejże zagłady beneficjentami3 ${ }^{33}$, co można zrozumieć jako ochronę tożsamości zbiorowej i patriotyczno-martyrologicznej narracji polskości.

Inną przyczyną było nałożenie się podziałów kulturowych na społeczno-ekonomiczne. Dyskurs Holokaustu i jego lokalne wersje były przez szerokie kręgi społeczne, niebędące beneficjentami transformacji, traktowane jako kulturowy wymiar rosnących nierówności społecznych i podziału na elity i masy (tak przynajmniej postrzegali świat nasi rozmówcy w latach 90., choć nie nadawaliśmy temu wówczas należytego znaczenia). Tego typu percepcja stanowi podatny grunt dla zachowań ksenofobicznych i wykluczających, w tym także odnoszących się do tych form pamięci, które nie są przez daną grupę uznawane za własne ${ }^{34}$.

Jeśli zaś chodzi o pamięć, którą nasi rozmówcy skłonni byliby uznać za własną, np. związaną z represjonowanymi przez PRL alternatywnymi wobec komunistycznych elementami narracji patriotyczno-martyrologicznej, to została ona uwolniona spod kontroli politycznej właśnie wtedy, gdy pamięć Holokaustu została zinstytucjonalizowana jako kamień węgielny mitu założycielskiego Unii Europejskiej i jedno z kryteriów oceny krajów Europy Wschodniej starających się o członkostwo w UE ${ }^{35}$. Ta szczególna synchronizacja oznaczała dla części polskiego społeczeństwa - w duchu antagonistycznym - negację jego odzyskanej pamięci, a skupienie uwagi na Holokauście - odmowę uznania za jednako istotne innych historycznych cierpień innych narodów ${ }^{36}$.

Asymetria pamięci europejskiej, przejawiająca się np. w uświadamianiu wschodnim Europejczykom, że - jak to ujął Tony Judt - uznanie centralnego

A. Leder Prześniona rewolucja. Ćwiczeniez logiki historycznej, Wydawnictwo Krytyki Politycznej, Warszawa 2014.

Por. A. Wimmer Nationalist Exclusion and Ethnic Conflict. Shadows of Modernity, Cambridge University Press, Cambridge 2002, s. 219.

A. Assmann Europe's Divided Memory, w: U. Blacker, A. Etkind, J. Fedor (eds.) Memory and Theory in Eastern Europe, Palgrave Macmillan, New York 2013, s. 27.

Por. D. Stone Beyond the Mnemosyne Institute: The Future of Memory after the Age of Commemoration, w: R. Crownshaw, J. Kilby, A. Rowland (eds.) The Future of Memory, Berghahn Books, New York-Oxford 2010, s. 28. 
miejsca Holokaustu jest „biletem wstępu” na europejskie salony ${ }^{37}$, budziła sprzeciw, werbalizowany następnie przez ugrupowania polityczne o charakterze nacjonalistycznym, które zresztą instrumentalizowały stosunek do przeszłości w swojej walce z elitami liberalnymi. Z kolei „zwykli ludzie”, z których rekrutowali się nasi rozmówcy, postrzegali swoją sytuację jako przejście od jednej formy ideologicznej kontroli pamięci do innej, która w podobny sposób uniemożliwiała im wyrażenie wizji przeszłości, którą uważali za swoją. Ponieważ zaś przejście to było związane z całkowitą przemianą ich świata, dokonującą się według ekonomicznych i politycznych wzorów z Zachodu, dyskurs Holokaustu stał się dla nich jednym z elementów ekonomicznej i kulturalnej kolonizacji, w ramach której „tubylcy” mieli zaakceptować kody kulturowe „Zachodniej Cywilizacji” bez wzajemności ze strony jej przedstawicieli ${ }^{38}$.

Obie strony miały trudności ze zrozumieniem swych antagonistów. Postrzeganie dyskursu Holokaustu jako zachodnioeuropejskiego instrumentu kontroli wschodnioeuropejskich peryferii było z zachodniej perspektywy interpretowane jako budzący grozę przejaw odrodzenia się wschodnioeuropejskich nacjonalizmów, stanowiących potencjalne zagrożenie dla europejskiej stabilności politycznej39 ${ }^{39}$ zaś wysiłki na rzecz uznania zbrodni komunistycznych jako integralnej części pamięci europejskiej były dezawuowane jako ukryta próba odwrócenia uwagi od uczestnictwa mieszkańców Europy Wschodniej w Holokauście ${ }^{40}$.

Z kolei wielu mieszkańców Europy Wschodniej, oburzonych tymi oskarżeniami, miało tendencję do traktowania zglobalizowanego dyskursu Holokaustu jako „pamięci ekranującej”, która służyła wyparciu innych zbrodni i wymazaniu lokalnych historii ${ }^{41}$, a także „eksterioryzacji” zła Holokaustu, związanej głównie z niemiecką polityką historyczną i przerzuceniem odpowiedzialności za zagładę Żydów na mieszkańców krajów, w których się ona dokonała. Dyskurs Holokaustu wymazywał w ich mniemaniu lokalną

37 T. Judt Postwar. A History of Europe since 1945, Penguin, New York 2005, s. 803.

38 S.C. Pearce Delete, Restart, or Rewind? Post-1989 Public Memory Work in East-Central Europe, "Sociology Compass" 2011 Vol. 5, No. 4, S. 262.

W. Outhwaite, L. Ray Social Theory and Postcommunism, Blackwell, Oxford 2005, s. 177-178.

M. Mälksoo Criminalizing Communism: Transnational Mnemopolitics in Europe, "International Political Sociology" 2014 No. 8, s. 82.

41 S. Craps, M. Rothberg Introduction: Transcultural Negotiations of Holocaust Memory, "Criticism" 2011 Vol. 53, No. 4, S. 518. 
historię komunistycznych prześladowań i stanowił próbę odwrócenia uwagi od odpowiedzialności Europy Zachodniej za powojenne losy mieszkańców krajów za żelazną kurtyną ${ }^{42}$.

Oczywiście nasi rozmówcy nie mieli przed 25 laty pełnej świadomości mechanizmów, które kształtowały ich stosunek do historii. Nie potrafili też tego stosunku precyzyjnie wyartykułować. Zrobili to za nich inni, którzy dzięki temu zyskali ich poparcie, a antagonizm pamięci stał się istotnym wymiarem kształtującego polskie życie polityczne konfliktu.

\section{Abstract}

\section{Sławomir Kapralski}

PEDAGOGICAL UNIVERSITY OF CRACOW

SWEDISH COLLEGIUM FOR ADVANCED STUDY (UPPSALA)

The Jews and the Holocaust in Polish Cultural Memory: Between Antagonism and Agon

25 years ago, Polish gentiles were interviewed on the disappearance of their Jewish neighbours. Kapralski re-examines those interviews in order to revise current attitudes to this kind of memory. He presents memory as a product of current constellations of the remembering subject's interests, whereby the subject is embroiled in existential efforts to construct mnemonic safety, which in turn is the basis for processes of reconstructing collective memory. These processes were particularly vital in the context of the uncertainty that marked the transformation in the 1990s - a transformation that Kapralski frames in terms of a structural trauma that shapes memories about historical trauma. Such a framing of memories of the Jews means that they have been publicly commemorated in Poland, but they are not remembered within the structures of communicative memory.

\section{Keywords}

mnéme, anámnesis, anti-Semitism, collective identity, mnemonic safety, trauma, Holocaust

42 M. Mälksoo Criminalizing Communism..., s. 84-85. 